\title{
咅展 望言
}

\section{副会長に就任して}

春山志郎

Shiro HARUYAMA

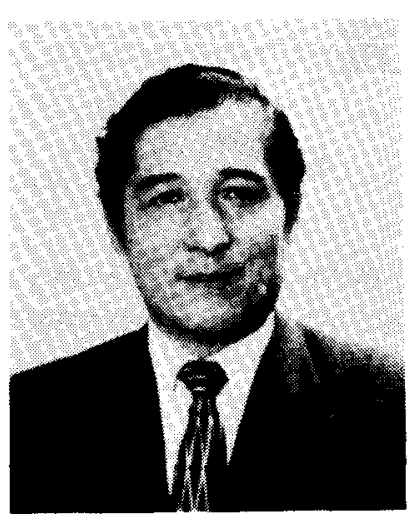

このたび, 電気化学協会副会長に就任することとなり, 電気化学 および工業物理化学分野における本協会の意義役割りなど改めて考 えさせられることが多い.

学協会がそれぞれ特定の学問あるいは技術分野を志向しているの はもちろんであるが，その設立あるいは発展過程が人ならびに社会 の流れに沿った歴史的産物である以上，その活動分野に異種なもの が混入したり，あるいは重大な欠落を生じることは避けられない，

一見異種なものであっても，学協会がその活動分野を拡げることは 歓迎するべきことであろう。しかし，活動分野に重大な欠落を生じ ることは好ましいことではない。それゆえ，学協会の現状を歴史的 産物として是認するばかりでなく，それを制御・修正するための学 協会の意志決定が必要となる.

学協会は, 研究の連絡・発表の場であり，また新しい情報の提供ならびに啓蒙活動もその役割りの一 つであろう. その両者間の比重により学協会の性格は微妙に变化する. その balance をとることは学 協会の重大な意志決定事項であり，その結果は会誌に強く反映される，欧米の学会に比し，日本の学協 会では後者の比重がやや重いように見える.

研究発表の場は，大会ならびに会誌である．講演発表ならびに報文投稿は会員の自由意志によるもの であるが，シンポジウムあるいは特集号など，学協会あるいは編集委員会の意志により特定の分野の研 究発表を掲載することができるし，またそれが必要である．しかし，ややもするとシンポジウム・特集 号が新規分野に限られる傾向があることを考慮する必要がある.

研究連絡の場は，支部ならびに各種専門委員会などであろう。地域的な連帯に基づく支部活動は，全 会員がいずれかの支部に属する点からきわめて重要な研究ならびに情報連絡の場であろう. しかし，や やもするとその活動は支部内に限られる傾向があるので，支部間あるいは支部，本部間の連絡に留意す る必要があろう。

委員会活動は専門分野に基づくものであり，支部活動と相まって，学協会の情報連絡組織を構成する はずである．しかしながら，多くの委員会は歴史的産物であり，学協会の全活動分野を cover しては いない. 上くに，これら委員会に所属する委員は全会員のほんの一部であり，その活動がきわめて活発 であるにせよ，学協会の中枢組織となるに至っていない，

以上のことを考慮すると, 電気化学協会の諸活動への全会員の参加を深めるための組織を作ってゆく ことが, 電気化学分野の進歩, 会員の增強, ひいては本協会が発展するための道ではないだろうか. 